\title{
Penguatan Kelembagaan Pengelolaan Kebun Raya Masenrenpulu Di Desa Batu Mila, Kecamatan Maiwa, Kabupaten Enrekang
}

\author{
Institutional Strengthening of Masenrenpulu Botanical Garden Management in Batu Mila \\ Village, Maiwa District, Enrekang Regency
}

\author{
Hadijah $^{1 *}$, Andi Nuddin ${ }^{1}$, Andi Erna Sriwahyuningsih ${ }^{1}$ \\ *Email: hadijah.umpar99@gmail.com \\ ${ }^{1}$ Program Studi Agribisnis. Fakultas Pertanian, Peternakan dan Perikanan. \\ Universitas Muhammadiyah Parepare
}

Diterima: 10 September 2021 / Disetujui: 20 Desember 2021

\begin{abstract}
ABSTRAK
Kebun Raya adalah kawasan konservasi eksitu yang memiliiki koleksi tumbuhan terdokumentasi dan ditata berdasarkan pola taksonomi, bioregion, tematik atau kombinasi dari pola-pola tersebut untuk mencapai tujuan kebun raya. Tujuan Kebun Raya yakni kegiatan konservasi, penelitian, pendidikan, wisata dan jasa lingkungan. Untuk mencapai tujuan, pengelolaan kebun raya diselenggarakan melalui sebuah kelembagaan sebagai penanggung jawab atau pelaksana kegiatan. Pengelolaan kebun raya masih terdapat masalah yang harus dibenahi. gagasan perubahan status dan organisasi serta penekanan kegiatan menjadi pusat konservasi tumbuhan, menambah tugas dan fungsi kebun raya. Untuk melaksanakan tugas dan fungsi tersebut, hal ini menjadi tanggung jawab dari pengelola kebun raya itu sendiri. Namun, dalam perkembangannya tugas dan fungsi kebun raya belum berjalan secara maksimal. Tujuan penelitian ini adalah : 1) Untuk mengetahui Lembaga-lembaga apa saja yang seharusnya terlibat dalam pengelolaan Kebun Raya Massenrempulu Enrekang. 2) Untuk mengetahui apa saja Langkah-langkah strategi yang dilakukan untuk mendukung penguatan kelembagaan dalam pengelolaan Kebun Raya Massenrempulu Enrekang. Peneltian ini memiliki 5 sampel responden dengan menggunakan metode sampel purposeve sampeling atau penetapan yang dilakukan secara sengaja dengan ketentuan sampel mewakili tugas dan fungsi masing-masing dengan metode penelitian deskriptif kualitatif, penelitian ini kemudian diolah menggunakan teknik analisis Interpretative Structural Modeling (ISM). Dari hasil penelitian diperoleh : Lembaga yang paling berperan dalam pengelolaan Kebun Raya Maserempulu dalam hasil penelitian ini adalan Dinas Lingkungan dengan nilai bobot Driver power 1.00 dan nilai bobot Dependent 0.21 . Program strategi yang paling disarankan dari hasil uji ISM adalah program strategi pengoptimalan perencanaan pengelolaan KRME dengan nilai bobot Driver Power 1.00 dan nilai bobot Dependent 1.00 .
\end{abstract}

Kata Kunci: Kebun Raya, Kelembagaan, Pengelolaan dan Konservasi

\section{ABSTRACT}

Botanical Garden is an ex-situ conservation area that has a documented collection of plants arranged according to taxonomic, bioregional, thematic patterns or a combination of these patterns to achieve the purpose of a botanical garden. The objectives of the Botanical Gardens are conservation, research, education, tourism and environmental services. To achieve the objectives, the management of the botanical garden is carried out through an institution as the person in charge or implementing the activities. There are still problems in the management of the botanical gardens that need to be addressed. the idea of changing status and organization and emphasizing activities to become a center for plant conservation, adding to the duties and functions of the botanical garden. To carry out these duties and functions, this is the responsibility of the botanical garden manager itself. However, in its development the tasks and functions of the botanical gardens have not run optimally. The aims of this study are: 1) To find out what institutions should be involved in the management of the Enrekang Massenrempulu Botanical Gardens. 2) To find out what are the 
strategic steps taken to support institutional strengthening in the management of the Massenrempulu Enrekang Botanical Gardens. This research has 5 samples of respondents using the purposive sampling method with the provision that the samples represent their respective duties and functions with a qualitative descriptive research method, this research is then processed using Interpretative Structural Modeling (ISM) analysis techniques. From the results of the study obtained: The institution that has the most role in the management of the Maserempulu Botanical Gardens in the results of this study is the Environmental Service with a weight value of 1.00 Driver power and a Dependent weight value of 0.21 . The most recommended strategy program from the ISM test results is the optimization strategy program for KRME management planning with a Driver Power weight value of 1.00 and a Dependent weighting value of 1.00 .

Keywords: Botanical Gardens, Institutional, Management and Conservation

(c) (i) This work is licensed under Creative Commons Attribution License 4.0 CC-BY International license

\section{A. PENDAHULUAN}

Konservasi adalah suatu upaya pelestarian atau perlindungan lingkungan alam yang dilakukan manusia namun masih memperhatikan manfaat yang bisa didaptkan pada saat itu degan cara tetap mempertahankan suatu keberadaan setiap komponen lingkungan untuk pemanfaatan di masa yang akan datang (Bitar, 2021), manfaat konservasi sendiri adalah untuk melindungi kekayaan ekosistem memelihara proses-proses ekologi maupun keseimbangan ekosistem secara berkelanjutan, melindungi spesies flora dan fauna yang hampir punah, melindungi ekosistem yang indah agar tetap menarik dan unik, serta melindungi ekosistem dari kerusakan yang disebabkan oleh faktor alam, mikro oerganisme dan dari hal lainya yang dapa merusak (Dlhkotabinjai, 2017).

Konservasi keanekaragaman hayati dilakukan secara insitu dan exsitu. Konservasi insitu adalah perlindungan terhadap spesies, variasi genetik dan habitat dalam ekosistem aslinya seperti cagar alam, suaka margasatwa, taman nasional dan lain-lain. Konservasi eksitu adalah metode atau alat perlindungan terhadap spesies tanaman, satwa liar dan organisme mikro serta varietas genetik diluar habitat aslinya. Kegiatan dalam konservasi eksitu meliputi penangkaran, penyimpanan dan pengklonan. Konservasi eksitu dilakukan karena alasan habitat mengalami kerusakan akibat konversi. Konservasi eksitu dapat digunakan sebagai tempat penelitian, percobaan, pengembangan produk baru atau pendidikan lingkungan.

Kegiatan dalam kebun raya meliputi kegiatan pemeliharaan dan pemanfaatan kawasan, pemeliharaan dan pemanfaatan koleksi tumbuhan serta pemeliharaan dan pemanfaatan infrastruktur atau sarana prasarana. Dalam melaksanakan kegiatan, kelembagaan kebun raya harus memiliki sumber daya manusia yang profesional 
dalam struktur organisasi, aturan main yang jelas serta fasilitas kebun raya berupa sarana dan prasarana yang memadai. Serta untuk mengelola kebun raya dengan area yang sangat luas dibutuhkan organisasi dan sumberdaya manusia yang besar, dengan penelitianpenelitian yang sangat maju, dengan fungsi konservasi dan pendidikan yang signifikan, serta dengan dukungan dana yang besar.

Pengelolaan kebun raya masih terdapat masalah yang harus dibenahi. Pernyataan Ramdani \& Sri Hidajati (2002) bahwa gagasan perubahan status dan organisasi serta penekanan kegiatan menjadi pusat konservasi tumbuhan, menambah tugas dan fungsi kebun raya. Untuk melaksanakan tugas dan fungsi tersebut, hal ini menjadi tanggung jawab dari pengelola kebun raya itu sendiri. Namun, dalam perkembangannya tugas dan fungsi kebun raya belum berjalan secara maksimal. Hal ini sejalan dengan pernyataan Didik (2011) bahwa sejumlah kebun raya ataupun arboretum yang dikelola oleh sejumlah perguruan tinggi dan institusi lainnya perkembangannya nampak tidak menggembirakan, terutama dengan fungsi dan perannya yang sangat terbatas, baik dalam hal penelitian, konservasi, pendidikan dan kegiatan peragaan.

Kebun Raya Massenrempulu Enrekang sebagai sebuah kebun raya yang baru dibangun tentu tak terlepas dari permasalahan tersebut. Kebun raya Enrekang yang bertemakan pengkoleksian tumbuhan kawasan Wallacea tentu harus bisa menjadi penopang konservasi tumbuhan wallacea dengan menjalankan fungsi sebagai kawasan konservasi, tempat penelitian dan kawasan ekowisata Pencapaian fungsi Kebun Raya Massenrempulu Enrekang sebagai sebuah kawasan konservasi harus memiliki kelembagaan pengelolaan yang bisa mengelola atau memanfaatkan kawasan kebun raya secara maksimal. Untuk mengetahui penyebab atau permasalahan sehingga pelaksanaan tugas dan fungsi kebun raya belum maksimal maka dilkukan penelitian dengan judul "Penguatan Kelembagaan Pengelolaan Kebun Raya Massenrempulu Enrekang”. Penelitian ini bertujuan : a). Untuk mengetahui Lembaga-lembaga apa saja yang seharusnya terlibat dalam pengelolaan Kebun Raya Massenrempulu Enrekang dan b) Untuk mengetahui apa saja Langkah-langkah strategi yang dilakukan untuk mendukung penguatan 
kelembagaan dalam pengelolaan Kebun Raya Massenrempulu Enrekang

B. METODE PENELITIAN

\section{Tempat dan Waktu}

Penelitian telah dilaksanakan di Desa Batu Mila Kecamatan Maiwa Kabupaten Enrekang dimulai pada bulan Agustus sampai bulan Oktober tahun 2020.

\section{Populasi dan Sampel}

Populasi dalam penelitian ini adalah orang-orang yang memahami tentang penguatan kelembangaan pengelolaan Kebun Raya Massenrenpullu Enrekang. Adapun untuk mengetahui penguatan kelembagaan pengolaan kebun raya hanya memerlukan populasi orang-orang dalam kelembagaan tertentu yang memiliki peranan besar dalam pengolaan kebun raya massenrenpullu.

Eriyantho dalam Agung (2017) menggunkan metode purposeve sampel atau penetapan yang dilakuka secara sengaja dengan ketentuan sampel mewakili tugas dan fungsi masingmasing. Menurut saaty dan eriyanto dalam agung (2017), penelitian dengan menggunakan model ISM tidak membutuhkan sampel yang banyak, sehingga jumlah sampel dalam penelitian ini ditetapkan sebanyak 5 orang.

\section{Jenis dan Sumber Data}

Sumber data yang diperlukan dalam penelitian ini meliputi data primer dan data sekunder. Data primer adalah data yang diperoleh dengan cara observasi langsung kelokasi penelitian dan mengadakan wawancara langsung terhadap responden dengan menggunakan daftar pertanyaan (kuesioner) yang telah disiapakan dengan tujuan penelitian.

Data sekunder adalah data yang diperoleh dari studi kepustakaan, laporan tahunan, atau data statistik bulanan terkait dari kelembagaan pengolaan kebun raya massenrenpullu Enrekang.

\section{Teknik Pengumpulan Data}

Tehnik pengumpulan data dengan melakukan teknik sebagai berikut:

a. Observasi yang dilakukan dengan cara mengamati secara langsung dengan kondisi yang ada pada lokasi penelitian.

b. Kuesioner klasifikasi pertanyaan yang dibuat oleh peneliti sebagai bahan pertanyaan untuk responden.

Tabel 1. Jumlah Pertanyaan Sub-Elemen

\begin{tabular}{|c|c|c|c|}
\hline Elemen & $\begin{array}{l}\text { Jumlah } \\
\text { sub } \\
\text { elemen }\end{array}$ & $\begin{array}{c}\text { Jumlah } \\
\text { pertanyaan }\end{array}$ & Karakteristik data \\
\hline A & 14 & 91 & $\begin{array}{l}\text { Lembaga yang seharusnya } \\
\text { berperan dalam pengelolaan } \\
\text { KRME }\end{array}$ \\
\hline B & 10 & 45 & $\begin{array}{lr}\text { Program strategi yang } & \text { diterapkan } \\
\text { seharusnya } & \text { diteran } \\
\text { dipengelolaan KRME }\end{array}$ \\
\hline
\end{tabular}


B. adalah elemen (variabel) Program strategi yang seharusnya diterapkan dipengelolaan KRME

Berdasarkan Tabel 1 dapat dijelaskan bahwa kuesioner adalah pengumpulan data dengan menggunakan daftar pertanyaan. melalui model Interpretative Structural Modeling (ISM). Adapun elemen-elemen yang digunakan pada penelitian ini adalah sebagai berikut:

a. Lembaga yang seharusnya berperan dalam pengelolaan KRME adalah sebagai berikut:

1) Dinas lingkungan hidup

2) Dinas pendidikan dan kebudayaan

3) Kebun Raya Bogor

4) LIPI (Lembaga ilmu pengetahuan indonesia )

5) Dinas Pemuda, Olaraga dan Pariwisata

6) Dinas pekerjaan umum (PU)

7) Porles

8) Dinas tenga kerja

9) Badan pertanahan

10) Dinas pertanian dan perkebunan

11) BPMD (balai pendidikan masyarakat desa)

12) BAPEDA (badan perencanaan pembagunan daerah)

13) Dinas penindustrian dan perdangangan
14) Dinas pendapatan daerah

b. Program strategi yang seharusnya diterapkan dipengelolaan KRME adalah sebagai berikut :

1) Pengembangan sumber daya manusia (SDM)

2) Pengembangan jaringan kerjasama kemitraan

3) Mengoptimalkan perencanaan pengelolaan KRME

4) Peningkatan fungsi koordinasi antar lembaga

5) Peningkatan sarana dan prasarana

6) Monitoring dan evaluasi

7) Pengembangan penelitian dan pendidikan

8) Penganekarangam sumberdaya hayati dan ekosistemnya

9) Penguatan kontrol dan pengawasan

10) Pengembangan objek wisata

\section{Analisis ISM}

Pengolaan data dilakukan secara manual dengan beberapa tahapan, yaitu:

a. Editing

Tahapan diawali dengan memeriksa kelengkapan, kejelasan, konsistensi dan kesesuaian jawaban responden apakah ada kesalah pahaman responden karena 
kurang mengertinya responden terhadap apa yang disampaikan terhadapnya.

b. Coding atau pengkodean jawaban responden

Penelitian ini mengunakan kode responden yang baku sehingga penyusuaian daftar kode tidak perlu dilakukan. Adapun kode jawaban menggunakan : V, A, X, dan atau O yang bermakna :

$\mathrm{V}$ adalah eij $=1$ dan $\mathrm{ije}=0$

A adalah eij $=0$ dan $\mathrm{ije}=1$

$\mathrm{X}$ adalah $\mathrm{eij}=1$ dan $\mathrm{ije}=1$

$\mathrm{O}$ adalah eij $=0$ dan $\mathrm{ije}=0$

Angka 1 dan 0 menunjukkan:

$1=$ ada hubungan kontestual antara eleman

$0=$ tidak ada hubungan antara kontestual antara eleman

c. Processing

Setelah data terkumpul dan diperikasa kelengkapannya selanjutnya secara manual data dikelompokkan sesuai dengan rencana analisis yang digunakan, kemudian diolah dan diproses sehingga jadi informasi yang bermanfaat bagi yang membutuhkan.

Interpretative Structural Modeling (ISM), digunakan untuk menganalisis bagaimana strategi penguatan kelembagaa pengelolaan Kebun Raya Massenrenpulu Enrekang. Tahapan-tahapan dalam analisis ISM sebagai berikut : a. Menyusun Structural SelfInteraction sub elemen sebelumnya, sebagai hasil pertimbangan kontekstual dengan menggunakan simbol V, A, X dan O.

b. Menyusun model structural (tingkat elemen) setiap elemen.

c. Menyusun Matrix (SSIM) adalah masukan (penilaian) dari responden terhadap sub-

d. Matrix Driver Power-Dependent (DP-P) yang terdiri dari 4 sektor seperti pada gambar

e. Menyusun model struktural (tingkat level) setiap elemen

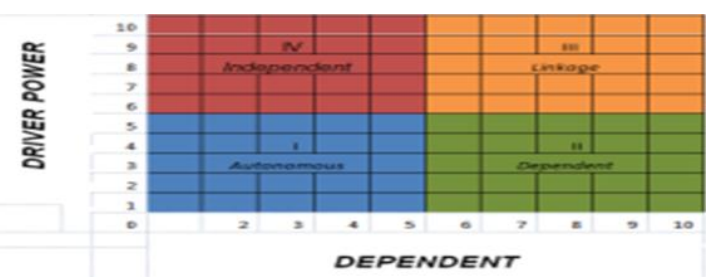

Gambar 1. Matrikx Driver PowerDependent (DP-D)

Keterangan :

Sektor I:

Autonomous $=$ weak driver weak dependent (sedikit terkain dengan sestem). Sub-elemen yang ada di posisi ini tidak terkait dengan program, atau hubungannya sangat singkat.

Sektor II:

Dependent $=$ weak driver-strong dependen (elemen tidak bebas). Sub-elemen yang ada di posisi ini tidak penting dalam hubungan program

Sektor III: 
Lingkage, sub-elemen yang ada di sektor ini sangat penting dan harus dikaji secara hatihati, karena hubungannya dengan sub-elemen lainnya tidak stabil. Maka dari itu setiap tindakan pada sub-elemen tersebut akan menghasilkan sukses, sebaliknya lemahnya perhatian terhadap sub-elemen ini akan menyebabkan kegagalan program.

Sektor IV :

Independent, sub-elemen di sektor ini merupakan variabel bebas, dimana kekuatan penggerak yang besar (driver-power), tetapi hanya punya sedikit ketergantungan terhadap yang lain.

\section{HASIL DAN PEMBAHASAN}

1. Program penguatan kelembagaan dalam pengelolaan kebun raya

Hasil analis ISM (interpretative structural modeling ) mengenai kelembagaan yang perlu dilakukan dalam pengembagan kebun raya massenrenpulu di Desa Batu Mila Kecamatan Maiwa Kabupaten Enrekang menunjukkan bahwa dari 14 sub-elemen yang diduga ada 6 diantaranya merupakan lembaga yang penting dalam pengelolaan kebun raya. Keenam-sub elemen tersebut terbagi dalam dua posisi yaitu independen dan lingkage, independent dan linkage memiliki daya penggerak (driver power) yang besar terhadap program penguatan kelembagaan (DP> 0,50), dan bedanya indenpendent kebergantungannya (dependent) terhadap sub-elemen lainya kecil $(\mathrm{D} \leq 0,50) \quad$ Sedangkan linkage kebertangunnya (dependen) terhadap subelemen lainya besar $(\mathrm{D}>0,50)$ Besar.

Berdasarkan tabel 4, ada faktor yang memiliki peran sangat lemah terhadap program yang masuk dalam penguatatan kelembagaan pengelolaan kebun raya massenrenpulu $(\mathrm{DP} \leq 0,50)$, yaitu (1) dinas tenaga kerja , (2) dinas penindustrian dan perdangangan. Kedua lembanga ini memiliki bobot dependent yang besar (D>0,50) yang menandakan bahwa kelembagaan tersebut memiliki peran yang sangat lemah terhadap penguatan kelembagaan pengelolaan kebun raya massenrenpulu. Namun demikian, suatu hal yang perlu diperhatikan pada temuan ini tidak berarti bahwa kelembagaan tersebut tidak memiliki peran sama sekali, akan tetapi sangat lemah dalam penguatan kelembagaan pengelolaan kebun raya massenrenpulu seperti Tabel 2. 
Tabel 2. Perbandingan Bobot DP-D Program Penguatan Kelembagan Pengelolaan Kebun Raya Massenrenpulu

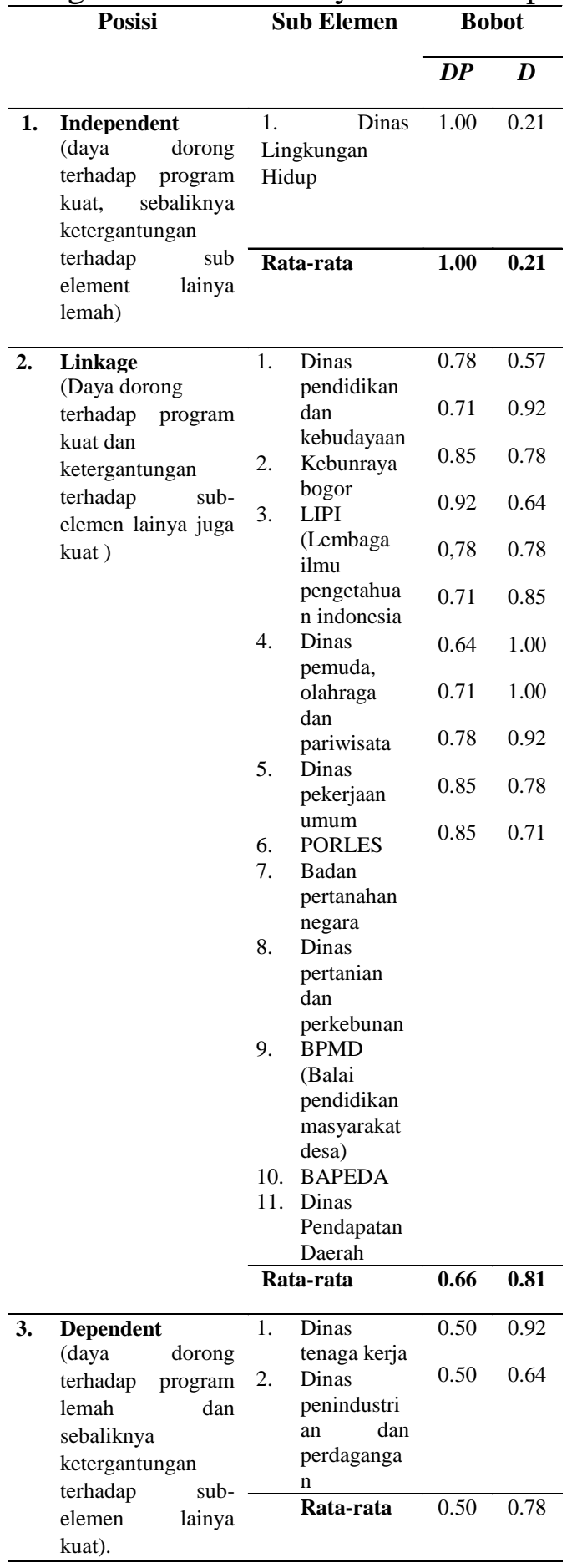

Perbandingan nilai driver power (DP) dan dependen (D) penguatan kelebagaan pengelolaan kebun raya massenrenpulu dapat dilihat lebih jelas pada Gambar 3.

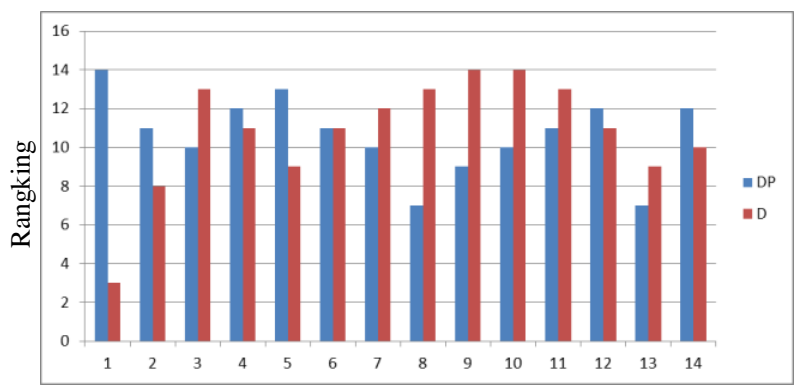

Gambar 3. Diagram Perbandingan Driver Power Dan Depedent Masing-Masing Penguatan Kelembagaan Pengelolalan Kebun Raya

\section{Keterangan :}

1. Dinas lingkungan hidup

2. Dinas pendidikan dan kebudayaan

3. Kebun Raya Bogor

4. LIPI (Lembaga ilmu pengetahuan indonesia )

5. Dinas Pemuda, Olaraga dan Pariwisata

6. Dinas pekerjaan umum (PU)

7. Porles

8. Dinas tenga kerja

9. Badan pertanahan

10. Dinas pertanian dan perkebunan

11. BPMD (balai pendidikan masyarakat desa)

12. BAPEDA (badan perencanaan pembagunan daerah)

13. Dinas penindustrian dan perdangangan

14. Dinas pendapatan daerah

\section{Penguatan \\ Kelembagaan \\ Pengelolaan Kebun Raya Massenrenpulu Enrekang Di Posisi Denpendent}

Hasil analisis ISM menujukan Dinas Lingkungan Hidup merupakan lembaga yang paling berperan dalam pengelolaan Kebun Raya Maserempulu Enrekang dengan nilai bobot $D P=1.00$ dan $D=0.21$, Dinas Lingkungan Hidup adalah lembaga yang saat ini paling 
beperan dalam pengelolaan KRME, dapat dilihat dari diagram posisi dibawah ini

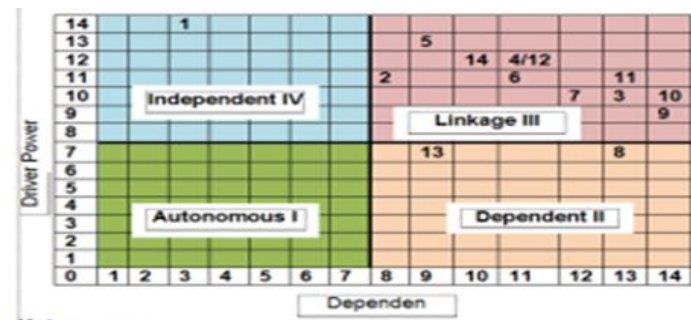

Gambar 4. Posisi Kelembagan

Pengelolaan Kebun Raya Massenrenpul Enrekang

Keterangan :

1. Dinas lingkungan hidup

2. Dinas pendidikan dan kebudayaan

3. Kebun Raya Bogor

4. LIPI (Lembaga ilmu pengetahuan indonesia )

5. Dinas Pemuda, Olaraga dan Pariwisata

6. Dinas pekerjaan umum (PU)

7. Porles

8. Dinas tenga kerja

9. Badan pertanahan

10. Dinas pertanian dan perkebunan

11. BPMD (balai pendidikan masyarakat desa)

12. BAPEDA (badan perencanaan pembagunan daerah)

13. Dinas penindustrian dan perdangangan

14. Dinas pendapatan daerah

Hal ini di karenakan tugas dan fungsi yang terdapat pada Dinas lingkungan hidup Kabupaten Enrekang. Dimana tugas tersebut adalah Merencanakan, mengkoordinasikan, melaksanakan dan mengendalikan kegiatan bidang tata lingkungan dan perlindungan sumbser daya alam, sedangkan fungsinya sendiri adalah. Penyusunan program dan kegiatan bidang tata lingkungan dan perlindungan sumber daya alam, pelaksanaan inventarisasi data dan informasi sumber daya alam, penyusunan dokumen RPPLH, pelaksanaan perlindungan, pemanfaatan secara lestari dan pencadangan sumberdaya alam serta inventarisasi gerakan rumah kaca, perencanaan penetapan dan kebijakan konservasi hayati, pemanfaatan berkelanjutan dan kerusakan keanekaragaman hayati (Perpub 2028), maka dari itulah Dinas Lingkungan Hidup menjadi lembaga yang menaungi Kebun Raya Maserempulu Enrkang.

\section{Penguatan Kelembagaan Pengelolaan Kebun Raya Massenrenpulu Enrekang Di Posisi Linkege}

Posisi Linkage terdapat sebelas lembaga yang berperan dalam pengelolaan KRME. Di antaranya adalah, Dinas pendidikan dan kebudayaan nilai bobot $D P=0.78, D=0.57$, Kebun raya bogor nilai bobot $D P=0.71, D=0.92$, LIPI (Lembaga ilmu pengetahuan indonesia) nilai bobot $D P=0.85, D=$ 0.78, Dinas pemuda olahraga dan pariwisata bobot $D P=0.92, D=0.64$, Dinas pekerjaan umum bobot $D P=0.78$, $D=0.78$, PORLES bobot $D P=0.71, D=$ 0.85 , Badan pertanahan negara bobot $D P$ $=0.64, D=1.00$, Dinas pertanian dan perkebunan bobot $D P=0.71, D=1.00$, BPMD (Balai pendidikan masyarakat desa) bobot $D P=0.78, D=0.92$, BAPEDA bobot $D P=0.85, D=0.78$ dan 
Dianas Pendapatan Daerah bobot $D P=$ $0.85, D=0.71$. Kebun raya maserempulu enrekng memiliki 600 jenis hayati yang dibudidayakan di dalamnya (Riska, Dkk. 2020), hal ini yang menjadi daya tarik bagi pengujung dari berbagai kalangan tidak terkecuali bagi pelajar atau mahasiswa yang ingin menambah penetahuan tentang ke anekaragam hayati. Dinas pendidikan dan kebudayaan menjadi lembaga yang berperan dalam menyedikan fasilitas pendidikan untuk KRME seperti, mengadakan kegiatan study tour dan sebagai lokasi penelitian untuk sekolah atau perguruan tinggi yang ingin berkunjung dan melakukan penelitian di kebun raya maserempulu enrekang.

Kebun raya maserempulu enrekang menurut Ir. Mursalim, MP (kadis Lingkungan Hidup Enrekang) salah satu responden dalam penelitian ini mengatakan, KRME masih menjadi kebun raya yang paling muda. KRME baru genap 10 tahun sejak diresmikan oleh bupati enrekang Ir. H. Latinro Latunrung (Riska, Dkk. 2020), maka dari itu kebun raya bogor (LIPI) memiliki peranan yang paling penting untuk penembangan KRME dalam hal pengenbangan hayati, diketahui tujuan dari perjajian kerja sama dengan kebun raya bogor untuk menyediakan media konservasi tumbuhan secara in-situ dan ex-situ, menyediakan media pendidikan dan laboraturium tropis, menambahkan objek wisata di kabupaten enrekang serta menyelamatkan dan melestarikan lahan strategis di kebupaten enrekang (Wilda, 2015). Dari tujuan di adakannya perjajian kerja sama antara KRME dan Kebun raya bogo (LIPI) maka bisa dilihat jika adanya keterkaiatan kerja sama yang kuat atara dinas pendidikan dan kebudayaan, dinas pemuda, olahraga dan pariwisata, badan pertanahan negara, dinas pertanian dan perkebunan serta dengan kebun raya bogor (LIPI). Dinas pemuda, olahraga dan pariwisata menjadi salah satu lembaga yang berperan dalam pengelolaan KRME menurut bapak Muh. Amin Dalle, SP,Msi Selaku sekertaris Disopar, Dinas pemuda, olahraga dan pariwisata harus memiliki peran dalam pengelolaan Kebun Raya Masenrepulu Enrekang mengingat KRME ini adalah salah satu objek wisata yang di miliki oleh Kabupaten Enrekang dengan daya tarik yang unik sehingga membutuhkan pengelolaan pariwisata yang baik. Seperti di lansir oleh Salim (2010) dalam penelitiannya dengan judul analisis strategi pengembangan kebun raya bogor sebagai objek wisata, maka diusung beberapa strategi guna 
mengembangkan objek wisata di kebun raya bogor seperti memperkuat aksesbilitas lintas kabupaten, mengembangkan kekhasan produk wisata alam, meningkatkan sarana dan prasarana, melakukan kerjasama pendidikan dan keterampilan dengan penyelenggaraan atau institusi pendidikan formal bidang kepariwisataan, melakukan pemasaran dan promosi secara inovatif, efektif dan efesien.

Semua kegiatan tidak terlepas dari peran dukungan oleh pemerintah daerah setempat. Seperti merumuskan kebijakan teknis perencanaan pembaguan daerah dan penelitian dalam hal pengelolaan KRME, hal ini dapat dilakukan oleh Bappeda sebagai institusi perencanaan daerah. Sesuai dengan Undang-Undang Nomor 32 tahun 2004 dan UndangUndang Nomor 25 Tahun 2004 Tentang SPPN, menuntut adanya proses perencanaan pembagunan yang lebih bersifat partisipatif. Dalam kaitan ini, BAPPEDA menerima tugas untuk membantu Bupati dalam penyelenggaraan pemerintah daerah dalam bidang perencanan pembangunan daerah. Bappeda memiliki fungsi untuk menyusun berbagai dokumen perencanan dalam bentuk Rencana Pembangunan Jangka Panjang Daerah (RPJPD), Rencana pembangunan Jangka Menengah Daerah (RPJMD) dan Rencana Kerja Pemerintah Daerah (RKPD). Disamping itu, juga melakukan fungsi lain yang berkenaan dengan koordinasi, pemantauan, evaluasi, monitoring dan pengendalian pembangunans serta penelitian dan pengembangan. Dengan fungsi-fungsi seperti itu, maka proses perencanaan perlu melibatkan berbagai pihak atau stakeholders, baik yang terlibat langsung dalam program-program yang dirumuskan dan pemanfaatan hasil-hasilnya melalui proses perencanan pembangunan daerah yang bersifat partisipatif. Perencanaan patisipatif terutama diperlukan untuk melakukan usaha yang lebih sistimatik dalam mengantisipasi permasaalahan pembangunan sosial ekonomi masyarakat yang mengarah kepada upaya-upaya meningkattkan kesejahteraan dan kualitas hidup masyarakat (Wordpress, 2011).

Polri dalam membangun dirinya harus selaras dengan pengembangan nasional yang memuat visi misi strategi pokok pembangunan, kebijakan dan sasaran serta program dan kegiatan. Salah satu misi polri adalah memelihara keamanan dan ketertiban masyarakat sepanjang waktu di seluruh wilayah serta memfasilitasi keikut sertaan masyarakat dalam memelihara ketertiban masyarakat 
di lingkungan masing-masing. Selaras dengan UU No.2 Tahun 2002 tentang fungsi Kepolisian Republik Indonesia yang di atur dalam pasal 2, bahwa fungsi kepolisian adalah salah satu fungsi pemerintah negara di bidang pemeliharaan keamanan dan ketertiban masyarakat, penegak hukum, perlindungan, pengayoman dan pelayanan kepada masyarakat (Satriya 2018). Dari misi serta fungsi yang dimiliki oleh polri mengngambarkan bahwa lembaga ini memiliki peranan dalam pengelolaan Kebun Raya masenrenpulu Enrekang dikarekankan KRME adalah salah satu fasilitas daerah dengan 600 spesies tanaman yg dibudidayakan serta menjad salah satu objek wisata yang banyak dikunjungi sehingga memerlukan pengaman, ketertiban dan perlindungan.

\section{Penguatan Kelembagaan \\ Pengelolaan Kebun Raya Massenrenpulu Enrekang Di Posisi Dependen}

Posisi Dependent terdapat dua lembaga. Yaitu Dinas Tenaga Kerja dan Dinas Penindustrian dan Perdagangan dalam penguatan kelembagaan pengelolaan KRME yaitu : Dinas tenaga kerja dan Dinas penindustrian dan perdagangan. Kelembagaan pada posis Dependen ini memiliki pengaruh yang sangat lemah di banding kedu posisi senbelumnya. Namun demikian, perlu diperhatikan bahwa tidak berarti strategi tersebut tidak memiliki peran sama sekli, namun sangat lemah dalam penelitian penguatan kelembagaan pengelolaan kebun raya massenrenpulu.

Posisi dari ke-empat belas kelembagaan dapat dilihat pada masingmasing bobot DP-D seperti tersaji pada tabel 3. Dari ke-empat belas lembaga Dinas Lingkungan menjadi lembaga yang paling berperan penting dalam pengelolaan KRME dilihat dari bobot DP $=1.00$ dan $\mathrm{D}=0.21$.

Kecilnya nilai Drive Power (DP) mengindikasikan jika sub-elemen pada penelitian ini merupakan lembaga yang tidak berperan penting dalam penguatan kelembagaan pengelolaan KRME, sedangkan Dependent (D) menujukan bahwa ketergantungannya terhadap subelemen yang ada pada posisi ini adalah tidak bebas. Artinya semua bergantung pada tindakan sub-elemen lainya, karena itu sub-elemen diposisi ini tidak penting.

Penguatan kelembagaan yang berperan penting dalam pengelolaan KRME pada level 1 adalah Dinas Lingkungan Hidup $(\mathrm{DP}=1.00 \mathrm{D}=0.21)$ pada level 2 terdapat Dinas Pemuda, Olahraga dan Pariwisata $(\mathrm{DP}=0.92 \mathrm{D}=$ 0.64) lalu pada level 3 ada BAPEDA (DP 
$=0.85 \mathrm{D}=0.78)$ LIPI (Lembaga Ilmu Pengetahuan Indonesia) $(\mathrm{DP}=0.85 \mathrm{D}=$ 0.75) dan Dinas Pendapatan Daerah (DP $=0.85 \mathrm{D}=0.71)$ di level 4 terdapat BPMD (DP $=0.78 \mathrm{D}=0.92)$ lalu Dinas Pekerjaan Umum $(\mathrm{DP}=0.78 \mathrm{D}=0.78)$ dan Dinas pendidikan dan Kebudayaan $(\mathrm{DP}=0.78 \mathrm{D}=00.57$ ) level 5 ada Dinas Pertanian dan Perkebunan $(\mathrm{DP}=0.71 \mathrm{D}=$ 1.00) Kebun raya Bogor $(\mathrm{DP}=0.71 \mathrm{D}=$ 0.92) dan Polres $(\mathrm{DP}=0.71 \mathrm{D}=0.85)$ sedangkan di level 6 hanya Badan Pertanahan $(\mathrm{DP}=0.64 \mathrm{D}=1.00)$ dan yang terakhir level 7 ada dua lembaga yaitu Dinas Tenaga Kerja $(\mathrm{DP}=0.50 \mathrm{D}=$ 0.92) dan Dinas Penindustrian ( $\mathrm{DP}=0.50$ $\mathrm{D}=0.64)$

\section{Program Strategi yang Seharusnya Diterapkan dalam Pengutan Kelembagaan Pengelolaan KRME}

\section{Analisis ISM (Interpretative}

Struktur Modelling) untuk mengetahui Program apa saja yang baiknya diterapkan untuk strategi penguatan kelembagaan pengelolaan Kebun Raya Masenrenpulu. Dalam peneitian ini terdapat sepuluh program strategi atau sub-elemen yang diduga, ke-sepuluh sub elemen yang diduga 5 diantaranya merupakan program strategi yang penting dalam pengelolaan kebun raya massenrenpulu. Ke-enam subelemen tersebut terbagi dan dua posisi yaitu Independen dan linkage, independen dan lingkage memiliki daya penggerak (driver power) yang besar terhadap program strategi penguatan kebun raya (DP > 0,50), dan bedanya independen dan kebergantungannya (dependen) terhadap sub-elemen lainya kecil $(\mathrm{D} \leq 0,50)$ sedangkan linkage kebergantunganya (dependen) terhadap sub-elemen lainya besar $(D>0,50)$ besar.

Faktor yang memiliki peran sangat lemah terhadap program yang masuk dalam strategi penguatan pengelolaan kebun raya $(\mathrm{DP} \leq 0,50)$, yaitu (1) pengembangan SDM , (2) Peningkatan sarana dan prasarana, (3) monitoring dan evaluasi dan (4) penguatan kontrol dan pengawasan. Keempat strategi ini memiliki bobot dependen yang besar (D>0,50) yang menandakan bahwa strategi tersebut memiliki peren yang sangat lemah terhadap penguatan kelembagaan pengelolaan kebun raya. Namun demikian, suatu hal yang perlu diperhatikan pada temuan ini tidak berarti bahwa strategi tersebut tidak memiliki peran sama sekli, akan tetapi sangat lemah dalam strategi penguatan kelembagaan pengelolaan kebun raya massenrenpulu seperti Tabel 3.

Perbandingan nilai driver power (DP) dan dependen (D) strategi penguatan 
pengelolaan kebun raya massenrenpulu dapat dilihat lebih Gambar 5.

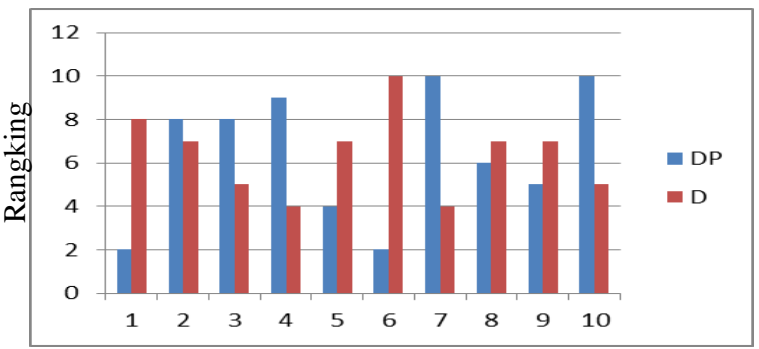

Gambar 5. Diagram perbandingan nilai DP-D masing-masing program strategi penguatan dalam pengelolaan Kebun

Raya Massenrenpulu Enrekang

\section{Keterangan :}

1. Pengembangan SDM

2. Pengembangan jaringan kerjasama kemitraan

3. Mengoptimalkan perencanaan pengelolaan KRME

4. Peningkatan fungsi koordinasi antar lembaga

5. Peningkatan sarana dan prasarana

6. Monitoring dan evaluasi

7. Pengembangan penelitian dan pendidikan

8. Penganekarangam sumberdaya hayati dan ekosistemnya

9. Penguatan kontrol dan pengawasan

10. Pengembangan objek wisata

\section{Program Strategi yang Diterapkan untuk Penguatan kelembagaan dalam Pengelolaan KRME Di Posisi Independen}

Hasil analisis ISM menunjukkan bahwa pada : posisi independent terdapat 4 strategi yaitu : Mengoptimalkan perencanaan pengelolaan KRME, Peningkatan fungsi koordinasi antar lembaga, Pengembangan penelitian dan pendidikan dan Pengembangan objek wisata yang merupakan prioritas dalam strategi penguatan

kelembagaan pengelolaan

KRME.
Strategi ini adalah merupakan peran penting dalam pengelolaan kebun raya.

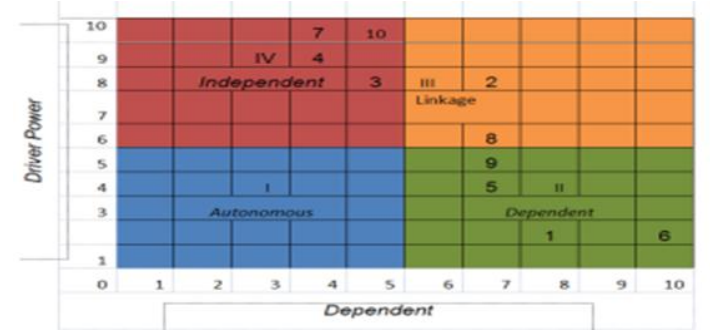

Gambar 6. Posisi $D P-D$ program strategi penguatan dalam pengelolaan Kebun Raya Massenrenpulu Enrekang

\section{Keterangan :}

1. Pengembangan SDM

2. Pengembangan jaringan kerjasama kemitraan

3. Mengoptimalkan perencanaan pengelolaan KRME

4. Peningkatan fungsi koordinasi antar lembaga

5. Peningkatan sarana dan prasarana

6. Monitoring dan evaluasi

7. Pengembangan penelitian dan pendidikan

8. Penganekarangam sumberdaya hayati dan ekosistemnya

9. Penguatan kontrol dan pengawasan

10. Pengembangan objek wisat

Empat sub-elemen pada posisi Independent Ini menjadi program paling strategi, mengingat KRME adalah sebuah kebun raya yang bertemakan pengkoleksian tumbuhan kawasan wallacea yang tentu harus bisa menjadi penopang konservasi tumbuhan wallacea dengan menjalankan fungsi sebagai kawasan konservasi, tempat penelitian dan kawasan ekowisata. Maka dari itu sub-elemen Mengoptimalkan perencanaan pengelolaan KRME, Peningkatan fungsi koordinasi antar lembaga, Pengembangan penelitian dan 
pendidikan dan Pengembangan objek wisata menjadi yang paling strategis. Dalam penelitian dampak ekonomi dan strategi pengelolaan kebun raya bogor sesuai daya dukung kawasan wisata oleh Isterah (2014), mengatakan strategi yang paling berpengaruh terhadap pengelolaan kawasan KRB yaitu penetrasi pasar. Potensi pasar wisatawan memiliki daya tarik yang tinggi terhadap KBR yang memiliki history akan sejarahnya serta memiliki jenis koleksi pohon dan tumbuhan dari berbagai macam negara, hal tersebut merupakan strategis eksternal yang menjadi peluang utama bagi KBR untuk meningkatkan sektor wisata. Strategi penetrasi pasar untuk pengelolaan objek wisata adalah strategi uang mengusahakan peningkatan pasar untuk produk dan jasa yang sudah ada saat ini melalui usaha pemsaaran yang lebih besar, meningkatkan keterampilan bagi tenaga kerja unit usaha, penambahan biaya untuk iklan dan promisi, dan pembuatan buku petunjuk serta pembuatan peta yang jelas sebagai petunjuk lokasi wisata.

\section{Program Strategi yang Diterapkan untuk Penguatan kelembagaan dalam Pengelolaan KRME Di Posisi Linkage}

Hasil analisis ISM pada program strategi Penguatan kelembagaan dalam pengelolaan KRME selain menujukan sub-elemen pada posisi Independent, hasil analisis ISM pada penelitian ini juga menujukan ada dua sub-eleme pada posisi Linkage di antaranya adalah : Pengembangan jaringan kerja sama kemitraan dan penganekaragaman sumberdaya hayati dan ekosistemnya. Ada dua lembaga yang Lembaga yang turut dalam pengelolaan KRME saat ini. Yaitu Lembaga Dinas Lingkungan Hibup dan LIPI, namun menurut Bapak Muh. Amin Dalle salah satu responden penelitian ini mengutarakan bahwa seharusnya ada beberapa lembaga yang turut bekerja sama dalam penguatan kelembagaan pengelolaan KRME ini salah satu lembaga yang diharapkan adalah lembaga Dinas Pemuda Olahraga dan Pariwisata, mengingat KRME adalah salah satu objek wisata yang memiliki daya tarik pengembangan sumber daya hayati. Dalam penelitian salim (2010) dalam penelitiannya menyebutkan ada sebelas strategi alternatif dalam mengembangkan KRB sebagai objek wisata tiga di taranya selaras dengan program strategi yang diterapkan untuk penguatan kelembagaan dalam pengelolaan KRME pada posisi linkage, ialah : melakukan kerjasama pendidikan dan keterampilan dengan penyelenggara 
atau institusi pendidkan formal bidang kepariwisataan, melakukan kerja sama dengan pemerintah daerah seluruh indonesia untuk mengirimkan daftar tumbuhan langka didaerah setempat dan mengembankagan kekhasan produk wisata alam yang ada di KRB.

\section{Program Strategi yang Diterapkan untuk Penguatan kelembagaan dalam Pengelolaan KRME Di Posisi Dependent}

Posisi dependent terdapat empat program strategi penguatan kelembagaan dalam pengelolaan KRME yaitu : pengembangan sumberdaya manusia, peningkatan sarana dan prasarana, monitoring dan evaluasi dan penguatan kontrol dan pengawasan. dimana keempat program strategi ini terdapat proses merencanakan, mengorganisasikan, memimpin dan mengendalikan pekerjaan anggota organisasi dan menggunakan semua sumber daya organisasi untuk mencapai sasaran organisasi yang diharapkan oleh KRME. Program strategi pada possisi Dependen ini memiliki pengaruh yang sangat lemah di banding kedu posisi senbelunya. Namun demikian, suatu hal yang perlu diperhatikan pada temuan ini tidak berarti bahwa strategi tersebut tidak memiliki peran sama sekali, akan tetapi sangat lemah dalam strategi penguatan kelembagaan pengelolaan kebun raya massenrenpulu.

\section{KESIMPULAN DAN SARAN}

Hasil penelitian dan pembahasan dapat ditarik kesimpulan bahwa lembaga yang berperan dalam pengelolaan Kebun Raya Maserempulu adalan Dinas Lingkungan Hidup, dinas pendidikan dan kebudayaan, kebun raya Bogor, lembanga ilmu pengetahuan indonesia (LIPI), Dinas Pemuda, Olahraga dan Pariwisata, Dinas pekerja umum, Porles, Badan Pertanahan, Dinas pertanian dan Perkebunan, Balai pendidikan masyarakat desa (BPMD), Badan perencanaan pembagunan daerah (BAPEDA) dan Dinas pendapatan daerah.

$$
\text { Program strategi yang dapat }
$$
mendukung penguatan kelembagaan pengelolaan kebun raya. Dari sepuluh program strategi itu yang merupakan program strategi kunci ada 6, (1) pengembagan jaringan kerja sama kemitraan, (2) mengoptimalakan perencanaan pengelolaan kebun raya massenrenpulu Enrekang, (3) peningkatan fungsi koordinasi antar lembaga, (4) pengembangan penelitian dan pendidikan, (5) penganekarangaman sumberdaya hayati dan ekosistemnya pengembangan objek wisata. 


\section{DAFTAR PUSTAKA}

Andi Nuddin. 2007. Analisis Sistem Kelembagaan Dalam Perencanaan Dan Strategi Pengelolaan Lahan Kritis Das Bila https://123dok.com / document / 8yd5dmeq - analisis sistem -kelembagaan-perencanaan strategi - pengelolaan - lahan kritis.html. (Diakses tanggal 27 Mei 2021)

Anonim 2018. Kabupaten Enrekang Provinsi Sulawesi Selatan/ https://sulselprov.go.id/pages/info_1 ain/5 (diakses pada tanggal 4 April 2021).

Badan Pusat Statistik Kabupaten Enrekang. 2020. Kecamatan Dalam Angka. 2020.

Bitar. 2021. Pengertian, tujuan, Manfaat dan Jenis Konservasi. https://www.gurupendidikan.co.id/k onservasi. (Diakses tanggal $14 \mathrm{Mei}$ 2021).

Destri. 2013. Konservasi tumbuhan di Kebun Raya Cibodas sebagai penyelamat keanekaragaman hayati pegunungan Indonesia Konservasi tumbuhan di Kebun Raya Cibodas sebagai penyelamat keanekaragaman hayati pegunungan Indonesia.

https://www.researchgate.net/profile /Andes_Rozak/publication/2835708 83 _ pdf. (Diakses tanggal 12 agustus 2020)

DidiK 2010 . Teknik dan Kelembagaan Pembangunan Kebun Konservasi Genetik. Makalah. Dipresentasikan pada lokakarya nasional "Status Konservasi dan Formulasi Strategi Konervasi Jenis Pohon-Pohon yang Terancam Punah (Ulin, Eboni, Michelia)". Bogor

Dihkotabinjai. 2017. Pengertian, tujuan manfaat an jenis macam konservasi. https:// www.google.com/ amp/ s / dihkotabinjai. wordpress.com. (Diakses taggal 14 Mei 2021)
Eriyanto dalam Agung. 2017. Ilmu Sistem: Meningkatkan Mutu Dan Efektivitas Manajemen. IPB Pres. Bogor. Analisis Strategis Peningkatan Produksi Kakao Dikecamatan Limboro Kabupaten Poliwali Mandar (skripsi sarjana). Fakultas Pertanian Universitas Muhammadiyah Parepare.

Istirah. 2014. Dalam Penelitian Dampak Ekonomi Dan Strategi Pengelolaan Kebun Raya Bogor Sesuai Daya Dukung Kawasan Wisata. Departemen Ekonomi dan sumberdaya lingkungan. Fakultas Ekonomi dan Manajemen. Institut Pertanian Bogor. https: // text - id . 123dok . com / dokument. (Diakses pada tanggal 27 Juni. 2021)

Lumintu, Galuh Dyah. 2017. Analisis Kelembagaan Rantai Pasok Produk Stik Tahu Menggunakan Metode Interpretive Structural Modelling (ISM) (Studi Kasus UKM Wijaya Kembar, Kota Kediri). http://repository.ub.ac.id/81 37. (Diakses tanggal 16 Mei 2021).

Massenrempulu Enrekang Sebagai Unit Pelaksana Teknis (UPT) Dinas Kehutanan Kabupaten Enrekang.

Muhammad Abdul. 2015 .Kebun Raya M assenrenpulu Enrekang. Https://Ww w.Academia.Edu/27418610/Kebun Raya_Messenrempulu_Enrekang_O leh_Kelompok_V_Lima. (Diakses 10 Juni 2020)

Muhammad Salim. 2010. Analisis Strategi Pengembangan Kebun Raya Bogor Sebagai Objek Wisata. Departemen Agribisnis, Fakultas Ekonomi dan Manajemen, Institut Pertanian Bogor 2010.

Perbup Enrekang 2018. Peraturan Bupati Enrekang Nomor 25 tahun 2018, Tentang Pembentukan Unit Pelaksana Teknis Kebun Raya Masserenpulu Pada Dinas Lingkungan Hidup. 
Perpres Nomor 93 Tahun .peraturan perundang-undangan tentang kebun raya

https://jdih.baliprov.go.id/produkhukum/peraturan-perundangundangan/perpres/5500 (diakses tanggal 5 juni 2021).

Perda kabupaten Enrekang 2011 https://www.hukumonline.com/pusa tdata/detail/pd731612201101/peratu ran-daerah-kabupaten-enrekangnomor-12-tahun-2011/document (diakses tanggal 5 juni 2021).

Pusat konservasi tumbuhan kebun raya .2016 .LIPI Http:// kebunraya daer ah. krbogor. lipi. go. id/ kebun raya massenrempulu enrekang.html. (Diakses 10 Juni 2020)

Putri Winata Septiani 2016. Peran Lembaga Pemberdayaan Masyarakat Kelurahan Dalam Memberdayakan Masyarakat Di Kelurahan Sungai Pagar Kecamatan Kampar Kiri Kabupaten Kampar. https://media.neliti.com/media/publi cations/199235-peran-lembaga pemberdayaan-masyarakat-ke. (Diakses tanggal 11 Juni 2020).

Ramdani \& Sri Hidajati dalam Taufik 2015. Analsis Peerencanaan Strategik Kebun Raya Bogor. Master Thesis. Institus Pertanian Bogor 2002.

Riska, Muhammadiah dan sudarmi. 2020. Peran Pemerintah dalam Pariwisata Kebun Raya Masenrempulu Enrekang. Ilmu administrasi Negara, Universitas Muhammadiyah Makassar, Indonesoa.

Rohman, Muhammad, dan Sofan Amri dalam taufik (2015). Manajemen Pendidikan (Analisis dan Solusi terhadap Kinerja Manajemen Kelas dan Strategi Pengajaran yang
Efektif). Jakarta: PT. Prestasi Pustakarya. 2012.

Satriya Nugraha. 2018. Hubungan Antara Kepolisisn dan Pemerintah Dalam Menegakkan Ketertiban Masyarakat. Universitas PGRI Palangka Raya.

Siregar Mustaid 2012. Peran LIPI dalam Pembangunan Kebun Raya Daerah. http:// lipi.go.id /berita /single /Peranan-LIPI-Dalam-

Pembangunan-Kebun-

Raya Daerah/7349.

(Diakses tanggal 10 agustus 2020)

Wilda Shyahratul. 2018. Valuasi Ekonomi Kebun Raya Maserempulu dengan Menggunakan Pendekatan Metode Biaya Perjalanan (Travel Cost Method) di Desa Milla Kecamatan Maiwa kabupaten Enrekang Sulawesi Selatan. Fakultas Kehutanan Universitas Hasanuddin Makassar.

Wikipedia 2020. Maiwa Enrekang Kecatan di Kabupaten Enrekang https://id.m.wikipwdia.org/wiki/Mai wa,_Enrekang (Diakses tanggal 4 april 2021).

Wordpress. 2011. Bappeda Enrekang. https ://

bapedaenrekang.wordpress.com / 2011 / 04 / 14 / hello-world. (Diakses tanggal 25 Juni 2021 
Tabel 3. Perbandingan Bobot $D P-D$ Program Strategi yang Diterapkan dalam Penguatan Kelembagaan dalam Pengelolaan KRME

\begin{tabular}{|c|c|c|c|}
\hline \multirow[t]{2}{*}{ Posisi } & \multirow[t]{2}{*}{ Sub Elemen } & \multicolumn{2}{|c|}{ Bobot } \\
\hline & & $\mathbf{D P}$ & $\mathbf{D}$ \\
\hline 1. Independen & 1. Mengoptimalkan perencanaan pengelolaan & 0,80 & 0,50 \\
\hline (Daya dorong terhadap & KRME & 0,90 & 0,40 \\
\hline program kuat, sebaliknya & 2. Peningkatan fungsi koordinasi antar lembaga & 1,00 & 0,40 \\
\hline ketergantungan terhadap & 3. Pengembangan penelitian dan pendidikan & 1,00 & 0,50 \\
\hline sub elemen lainya lemah) & 4. Pengembangan objek wisata & & \\
\hline & Rata-rata & $\mathbf{0 , 9 2}$ & $\mathbf{0 , 4 5}$ \\
\hline 2. Linkage & 1. Pengembangan jaringan kerjasama kemitraan & 0,80 & 0,70 \\
\hline $\begin{array}{l}\text { (Daya dorong terhadap } \\
\text { Program Kuat, } \\
\text { danKetergantungan }\end{array}$ & $\begin{array}{l}\text { 2. Penganekarangam sumberdaya hayati dan } \\
\text { ekosistemnya }\end{array}$ & 0,60 & 0,70 \\
\hline $\begin{array}{l}\text { Terhadap sub elemen } \\
\text { lainya juga kuat) }\end{array}$ & Rata-rata & $\mathbf{0 , 7 0}$ & $\mathbf{0 , 7 0}$ \\
\hline \multirow{5}{*}{$\begin{array}{l}\text { program lemah, } \\
\text { sebaliknya } \\
\text { ketergantungan } \\
\text { sub-elemen lain }\end{array}$} & 1. Pengembangan SDM & 0,20 & 0,80 \\
\hline & 2. Peningkatan sarana dan prasarana & 0,40 & 0,70 \\
\hline & 3. Monitoring dan evaluasi & 0,20 & 1,00 \\
\hline & 4. Penguatan kontrol dan pengawasan & 0,50 & 0,70 \\
\hline & Rata-rata & $\mathbf{0 , 3 2}$ & $\mathbf{0 , 8 0}$ \\
\hline $\begin{array}{l}\text { DP-D } \leq 0.50=1 \\
\text { DP-D } \geq 0.50=\end{array}$ & & & \\
\hline
\end{tabular}

